\title{
The Correlation between Breakfast with Level of Concentration in Elementary School's Pupils in Denpasar City
}

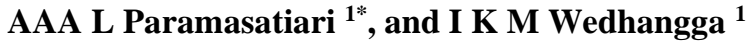 \\ ${ }^{1}$ Faculty of Medicine, Warmadewa University, Jl. Terompong No 24, Denpasar 80235, Indonesia \\ *1ilaparama84@gmail.com
}

\begin{abstract}
Breakfast is a meal in the morning, shortly after waking up to 10 (ten) AM. This activity has a purpose to fulfill the body nutrition in the morning before starting the activity. Breakfast is considered important for a pupils which sometimes has a very solid activity in school. In addition, in the academic process pupils need to be in a healthy body condition and have good attention and concentration to catch all the lessons in school. The aim of this research was to find out the correlation between breakfast with the level of concentration in elementary school's pupils in Denpasar City 2017. The research design was descriptive analytical through cross-sectional approach which was analyzed using Chi-Square statistical test by Statistical Package for the Social Sciences for Windows 16.0 (SPSS) program. The research data was primary data gathered with questionnaire form. The amount of the subjects were 96 persons which was selected using multistage cluster random sampling method to an elementary school's pupils in Denpasar City. The percentage of non-breakfast subject was 35 persons $(36,5 \%)$ and the breakfast subject was 61 persons $(63,5 \%)$. The percentages of Concentrations level of breakfast pupils were divided in three categories which were Low $(11,48 \%)$, Medium $(65,57 \%)$ and High $(22,95 \%)$. The result was showed that there was a significant relationship $(\mathrm{p}<0,05)$ between breakfast with the level of concentration. The conclusions could be drawn that there was a positive mild relationship between the two variables. It was recommended that this research can contribute as a source of information and evaluation for the development of science in the future.
\end{abstract}

Keyword : Correlation, Concentration, Elementary School.

\section{Introduction}

Breakfast is an eating activity in the morning before starting other activities. Breakfast is good at 06.00 a.m. until 10:00 a.m. by eating foods that contain balanced nutrition and can meet $20 \%-25 \%$ of total energy needs before learning activities at school are started [12]. Therefore, breakfast is often defined as a very important activity to start the day. The food composition for breakfast varies in each country. In Indonesia the most popular food for breakfast for children aged 6-12 years is white rice (28.5\%), fried egg / omelet, vegetables with gravy, fried fish, instant noodles, fried rice, and mineral water [9]. A good and routine breakfast can reduce the risk of cardiometabolic disease, reduces the risk of obesity $[1,18]$ and can improve academic abilities and achievements of children at school [18][6][3][12]. An aptomal nutritional intake in breakfast is believed to help the process of thinking, improve memory, and help solve problems [12]. The very first food consumed as breakfast should contain nutrients that are good for the body, and contain sufficient carbohydrates. 
Carbohydrates will be converted into glucose which will be used as fuel by brain cells, because neurons in the brain are not able to store the glucose, so the brain only relies on glucose intake from the bloodstream [12].

The 2013 Ministry of Health Regulation states that Indonesian children aged 10-13 years need 2,100 calories per day. Breakfast contributes up to $\pm 20 \%$ of calorie intake. This means that \pm 420 calories should come from the food consumed at breakfast, [9] while the remainder is filled at lunch, dinner and some interlude food. In Indonesia there are still many children, who are of school students' age, who do not get breakfast. Such condition causes the children to lose $20-60 \%$ of micronutrients such as iron, vitamin B, vitamin D and folate, [2] which are very useful for the growth and development of the children.

Basic Health Research states that $16.9 \%-50 \%$ of school-aged children and adolescents, and an average of $31.2 \%$ of adults in Indonesia do not have the habit of having breakfast [15]. This is led by various factors such as economic conditions, knowledge, job of parents, even the distance form home to school can also be a factor that can affect the absence

of children's habits to eat breakfast. [13]. This situation results in children not to get a healthy breakfast in

the morning. They only consume drinks at breakfast $(26.1 \%)$, such as water, milk or tea and $44.6 \%$ consume low-quality breakfast [12]. Ignoring breakfast eating activities also brings on a decrease in children's attention, concentration, and memory while studying at school [8]. If the decrease in attention and concentration continues, it is feared that it will affect children's learning achievement. Parents certainly expect to have healthy children and can excel in academic and non-academic fields, as well as educators do too, because children are the nation's investment in the future. Given the importance of breakfast activities in order to achieve learning achievement, this study is designed to prove the relationship between the two variables with the subject of the study, that is the elementary school children, in which, the study is conducted in Denpasar city, an area with many and varied population varieties, having high mobility, and later is expected to become a pilot area for other regions in Bali.

\section{Method}

\subsection{Location of the Study}

This study is conducted in October-December 2017 at several elementary schools in Denpasar.

\subsection{Design and Subject of the Study}

The study is designed by applying descriptive research method with a cross-sectional approach. The study is carried out on 96 samples, elementary school students aged 10-12 years who are selected using a simple two stages random sampling method. The selected elementary schools are SD Negeri 19 Pemecutan, SD Negeri 27 Pemecutan, and SD Harapan Mulia of Denpasar.

\subsection{Variables and Methods of Data Collection}

There are two variables in this study, namely the independent variable and the dependent variable. Eating breakfast is an independent variable and concentration is the dependent variable. The variable of breakfast is measured through questionnaire distribution, while the variable of concentration is measured using the Blanco Concentration Grid Test (BCGT). 
There are three categories of BCGT assessment, namely, Good, Moderate, and Poor. It is categorized as good if the respondent succeeds in finding the number $\geq 20$ in sequence, categorized as moderate if the respondent is only able to find the number 11-20, and categorized as poor if the respondent is only able to find the numbers 0-11.Data collection is done at one time. In other words, the researcher distributes the questionnaire to the respondent to be filled out and once it is filled out, the results are collected on the same day.

\subsection{Data Analysis Technique}

The data category on the variable of breakfast is divided into two, namely "eating breakfast" and "not eating breakfast". Variables of concentration are divided into three categories, namely, "Good", "Medium", and "Bad". Data are analyzed using descriptive univariate analysis and chi-square statistical test. Meanwhile, relationship strength measurements are carried out by the contingency coefficient test. However, the analysis of all data is carried out in the program of Statistical Package for the Social Sciences for Windows (SPSS).

\section{Results And Discussion}

The results of data analysis obtained from sample data in the study are shown in table 1.

Table 1. Characteristic of Sample

\begin{tabular}{|c|c|}
\hline Characteristics & Frequency $\%$ \\
\hline \multicolumn{2}{|l|}{ Sex } \\
\hline Male & $54(56,2)$ \\
\hline Female & $42(43,8)$ \\
\hline \multicolumn{2}{|l|}{ Age } \\
\hline 10 years & $24(25,0)$ \\
\hline 11 years & $46(47,9)$ \\
\hline 12 years & $26(27,1)$ \\
\hline \multicolumn{2}{|l|}{ Breakfast } \\
\hline Eating Breakfast & $61(63,5)$ \\
\hline Not Eating Breakfast & $35(36,5)$ \\
\hline \multicolumn{2}{|l|}{ Concentration Level } \\
\hline Poor & $17(17,7)$ \\
\hline Modeate & $64(66,7)$ \\
\hline Good & $15(15,6)$ \\
\hline
\end{tabular}

In terms of gender, the characteristics of respondents are dominated by male, whereas in terms of age, the majority of respondents are children aged 11 years old. As many as $63.5 \%$ of the respondents eat breakfast and the concentration level is dominated by the concentration level in the moderate category, which is by $66.7 \%$. As shown in table 2, there are more respondents who eat breakfast and have moderate and good concentration levels compared to those who do not eat breakfast. Among respondents who do not eat breakfast, most of them tend to have poor levels of concentration. The strength of relationships can be seen from the value of (r) which is 0.299 , which implies that the relationship between the two variables is a mild relationship [18]. 
In this study of the relationship between breakfast eating and concentration level in elementary school students in Denpasar, the characteristics of respondents were divided into two groups, based on age and by genre. Sorting out the respondents was done by considering the inclusion and exclusion criteria. All respondents who participated in this study were declared healthy and willing to follow the process of the study. Male genre dominate the group of respondents in terms of genre, with the number being 54 people $(56.2 \%)$. In terms of age, respondents were divided into three groups, namely, those aged 10 years, those aged 11 years, and those aged 12 years. Respondents aged 11 years were the respondents with the most high in number in this study, namely as many as 46 people or $47.9 \%$ of the total respondents, while the remaining aged 12 years is 26 people or equal to $27.1 \%$, followed by respondents with respondents aged 10 years, as many as 24 people or equal to $25.0 \%$. Breakfast, which is often forgotten, essentially fulfills the nutritional and energy needs of the day. Judging from the results of data analysis, there are still $36.6 \%$ of all respondents who do not eat breakfast or eat breakfast but with food that is not of high quality.

Table 2. Cross Tabulation

\begin{tabular}{llllllll}
\hline & & \multicolumn{3}{c}{ Concentration Level } & \multirow{2}{*}{ Total } & \multirow{2}{*}{ r } & \multirow{2}{*}{ P } \\
\cline { 3 - 5 } & & \multicolumn{2}{c}{ Poor } & Moderate & Good & & \\
\hline Breakfast & Eating & 10 & 24 & $1(2,8 \%)$ & $35(36,6 \%)$ & 0,299 & 0,009 \\
& Breakfast & $(28,6 \%)$ & $(68,6 \%)$ & & & & \\
& Not Eating & $7(11,5 \%)$ & 40 & 14 & $61(63,4 \%)$ & & \\
& Breakfast & & $(65,6 \%)$ & $(22,9 \%)$ & & & \\
& Total & 17 & 64 & 25 & $96(100 \%)$ & & \\
\hline
\end{tabular}

Perdana's study in 2013 which found that $\pm 69.6 \%$ of Indonesian children did not consume breakfast regularly and with quality food according to the balanced nutrition guidelines [14]. In fact, with a routine and quality breakfast children can be precluded from various risks of disease in the future [18][1]. Breakfast plays a very important role in children's readiness to go through their days, especially in children who are undergoing an academic process. If a child does not get good nutrition and calories, it will affect their learning process at school. This fact was also conveyed by Adolphus in 2013, that the breakfast eating habits can affect children's behavior, cognitive, and concentration [2]. If this continually takes place, a decline in children's learning achievements in school can allegedly occurs, even it can disrupt the process of development and growth of the crildren. The habit of ignoring the time to eat breakfast for children can be triggered by a variety of factors, such as gender, the availability of breakfast dishes, breakfast menus, nutritional knowledge, the distance of home to school, and the amount of pocket money [13].

Viewed from the level of concentration, there are 15 respondents who have good concentration levels, 64 have moderate concentration levels, and 17 others have poor concentration levels. These diverse results can be led by influential factors, one of which is the physical condition of the respondent. Sunawan in 2009 claimed that physical factors are one of the factors that play a significant role in a person's concentration process, especially for those who are doing learning activities [17].

Concentration in the learning process has a considerable influence, for example, when someone gets information or teaching material, he must be able to receive information that is conveyed well through focused attention [16]. If someone is in a state of being sick, sleepy, hungry, thirsty, or in a state of sensory disturbances, and respiratory problems, the concentration on learning will be disrupted [17]. Maintaining the condition of the body to 
remain in the best condition can be done by exercising regularly and eating any sufficiently energy and nutritional food that is appropriate for age regularly. With a healthy body, a person will be well-prepared to face daily activities and avoid various physical factors that can reduce his or her alertness and concentration.

Based on the results of the analysis of the relationship between the two variables of this study, it can be learned that there is a significant relationship between breakfast eating and concentration level in elementary school students in Denpasar. These results are formulated by looking at the results of data analysis that shows the value of the Pearson Chi-Square test $(9,447)$ which is greater than Table Chi-Square $(5,991)$ and the significance value of 0,009 and smaller than 0.05. These results reject the Zero (Ho) Hypothesis, and accept the Alternative Hypothesis (Ha), so it can be stated that there is a relationship between breakfast eating and concentration level in elementary school students in Denpasar. The strength of the relationship between the two variables can be seen from the results of the contingency coefficient which is 0.299. The relationship is a mild and positive relationship, which means that if the variable of eating breakfast is modified, the variable of concentration level will also change [19]. The relationship can also be seen roughly in cross tabulation between the two variables, in which, there are 14 respondents who eat breakfast and have a good concentration level and only 1 respondent does not eat breakfast and has a good concentration level. The results of the analysis that have been carried out show that breakfast is one of the factors that have a statistically significant effect on one's concentration level. This becomes worse if the decline in concentration level is experienced by a student who is required to concentrate fully in the academic situation at school. A decrease in the level of concentration during learning that takes place continuously, even, can cause a decrease in children's performance in school. The study conducted by Iqbal in 2015 on children / students at Sekolah Dasar Negeri 1 Karangasem, Laweyan Subdistrict, Surakarta City, showed that breakfast contributed to supporting children's learning abilities in school, so many children, who regularly eat breakfast, tend to obtain a good learning achievement [10]. Breakfast has a very important role because it can meet the body's energy needs in the morning after almost 9 hours of fasting. A study conducted by Arifin in 2015 against students of SD Al-Fathimiyyah, showed that eating breakfast is an important factor that supports the concentration of student learning in school. This was proven by the data listed, as many as 37 students, out of a total of 59 students examined, those who ate breakfast had a good concentration [4]. To maintain a good metabolic rate, the continuity of the supply of energy derived from glucose that is needed, consumption of breakfast is necessarily required in providing sufficient energy in the morning [5]. Eating breakfast has been shown to have an impact on the workings of the body system and the improvement of the nutritional status of children, in which, during his development a child needs a lot of energy and nutrition to support his physical growth, brain growth, and the work ability of his brain [7]. This happens because in the physiological processes of the brain and central nervous system, a lot of energy intake obtained from the digestion of food carbohydrates is very necessary [11], and this carbohydrate is needed for the process of forming ATP which will later become fuel for brain cells to work. If the carbohydrate intake as an energy supply is insufficient, the brain certainly will not work optimally in carrying out its functions as a regulator of memory, concentration, and attention [8]. In addition, skeletal muscles also need energy to work. If the two organs do not have maximum nutritional and energy intake, the effects triggered can be the symptoms of weakness, dizziness, and a decrease in attention. 


\section{Conclusions}

There is a statistically significant relationship between breakfast eating and concentration levels in elementary school students in Denpasar $(0.009<0.05)$. The relationship between breakfast eating and the concentration level is mild (0.3) and is positive, which means that if the variable of eating breakfast is modified, it will affect the variable level of concentration.

\section{References}

[1] Adamsson, V., Reumark, A., Marklund, M., Larsson, A. \& Risérus, U. Role of a prudent breakfast in improving cardiometabolic risk factors in subjects with hypercholesterolemia: A randomized controlled trial. Clinical Nutrition, 34, 20-26. Available from: https://www.sciencedirect.com (2015)

[2] Adolphus, K., Lawton, C. L. \& Dye, L. The effects of breakfast on behavior and academic performance in children and adolescents. Frontiers in Human Neuroscience, 7, 425. Available from : https://www.ncbi.nlm.nih.gov (2013)

[3] Adolphus, K., Lawton, C. L. \& Dye, L. 2015. The Relationship between Habitual Breakfast Consumption Frequency and Academic Performance in British Adolescents. Frontiers in Public Health, 3, 68. Available from : https://www.ncbi.nlm.nih.gov (2015)

[4] Arifin, L. A. \& Prihanto, J. B. Hubungan Sarapan Pagi Dengan Konsentrasi Siswa Di Sekolah. Jurnal Pendidikan Olahraga dan Kesehatan. (2015)

[5] Desmukh-Taskar,P.R.,Nicklas,T.A.,O' neil, C., Keast,D.R., Radcliffe, J.D., Cho, S. The Relationship of Breakfast Skipping and Type of Breakfast Consumption with Nutrient Intake and Weight Status in Children and Adolescents.The National Health and Nutrition Examination Survey.J Am Diet Assoc.110:869-878 (2010)

[6] Edefonti, V.,Rosato, V., Parpinel, M., Nebbia, G., Fiorica, L., Fossali, E., Ferraroni, M., Decarli, A. \& Agostoni, C. The effect of breakfast composition and energy contribution on cognitive and academic performance: a systematic review. Am J Clin Nutr, 100, 626-56.(2014)

[7] Ethasari, R. K. \& Nuryanto, N. Hubungan Antara Kebiasaan Sarapan Dengan Kesegaran Jasmani Dan Status Gizi Pada Anak Sekolah Dasar Di Sd Negeri Padangsari 02 Banyumanik. Journal of Nutrition College, 3, 7. (2014)

[8] Gajre, N. S., Fernandez, S., Balakrishna, N. \& Vazir, S. Breakfast eating habit and its influence on attention-concentration, immediate memory and school achievement. Indian Pediatr, 45 , 824-8. (2008)

[9] Hardinsyah \& Aries, M. Type of Food for Breakfast and its Roles in Daily Nutrient Intakes of School Age Children 6-12 Years in Indonesia. Jurnal Gizi dan Pangan, 7, 89-96. (2015)

[10] Iqbal, F. M. T., N. Juni Basuki,Sri Wahyu. Hubungan Antara Kebiasaan Sarapan Pagi Dan Prestasi Belajar Anak Sekolah Dasar. Skripsi, Muhammadiyah Surakarta.(2015)

[11] Irawan, M.A., 2007. Glukosa dan Metabolisme Energi. Sport Science Brief.1(6):12-5.

[12] Khalida, E., Fadlyana, E. \& Somasetia, D. H. 2015. Hubungan Kebiasaan Sarapan dengan Prestasi Belajar dan Fungsi Kognitif pada Anak Sekolah Dasar. Sari Pediatri, 17. (2015)

[13] Nofitasari, A., Anggorodi, R. A. \& Triyanti, T. Perilaku Sarapan Pagi Dan Kaitannya Dengan Prestasi Belajar Siswi Sekolah Menengah Pertama Di SMPN 2 Depok. Jurnal Kesehatan Masyarakat Andalas, 3, 46. (2009) 
[14] Perdana, F. 2013. Analisis Jenis, Jumlah, dan Mutu Gizi Konsumsi Sarapan Anak Indonesia. Jurnal Gizi dan Pangan, 8, 39. (2013)

[15] Rikesdas 2010. Laporan Nasional Riset Kesehatan Dasar. In: INDONESIA, K. R. (ed.). Jakarta: Badan Penelitian dan Pengembangan Kesehatan.(2010)

[16] Siswanto. Kesehatan Mental; Konsep Cakupan dan Perkembangannya. Yogyakarta: penerbit C.V ANDI OFFSET 15 (2007)

[17] Sunawan. 2009, Diagnosa Kesulitan Belajar. Semarang : UNNES

[18] So, .-Y. Association between Frequency of Breakfast Consumption and Academic Performance in Healthy Korean Adolescents. Iranian Journal of Public Health,42,25-32. (2013)

[19] Widarsa, K. T. 2013, Pedoman Analisis Statistika dengan SPSS, Denpasar :Universitas Warmadewa, 64-65 